Cahiers $d u$ MONDE RUSSE

\section{Cahiers du monde russe}

Russie - Empire russe - Union soviétique et États indépendants

$53 / 1 \mid 2012$

Pratiques du droit et de la justice en Russie (XVIIIe-XX siècles)

\title{
«ДАБЫ РОЗЫСКИ И ПЫТКИ МОГЛИ ЧИНИТЦА ПОРЯДОЧНО, КАК УКАЗЫ ПОВЕЛЕВАЮТ»
}

\section{ЭВОЛЮЦИЯ ТЕОРИИ И ПРАКТИКИ «РОЗЫСКНОГО» ПРОЦЕССА В РОССИИ}

ПЕРВОЙ ПОЛОВИНЫ XVIII В

"So that criminal investigations and torture be properly conducted, as prescribed by law". Evolution in the theory and practice of criminal investigations in Russia during the first half of the eighteenth centuryL'évolution théorique et pratique des procédures d'enquête criminelle en Russie dans la première moitié du XVIII siècle "Afin que les investigations et la question soient administrées convenablement, comme le prescrit la loi ». L'évolution théorique et pratique des procédures d'enquête criminelle en Russie dans la première moitié $\mathrm{du} \mathrm{XVIII}^{e}$ siècle

\section{Евгений Акельев еt Галина Олеговна Бабкова}

\section{OpenEdition}

Journals

\section{Édition électronique}

URL : http://journals.openedition.org/monderusse/9362

DOI : $10.4000 /$ monderusse. 9362

ISSN : $1777-5388$

Éditeur

Éditions de l'EHESS

Édition imprimée

Date de publication : 15 mars 2012

Pagination : 15-39

ISBN : 978-2-7132-2390-7

ISSN : $1252-6576$

\section{Référence électronique}

Евгений Акельев и Галина Олеговна Бабкова, « «Дабы розыски и пытки могли чинитца порядочно, как указы повелевают» », Cahiers du monde russe [Онлайн], 53/1 | 2012, Выложить онлайн 02 avril 2015, Наводить справки в 30 avril 2019. URL : http://journals.openedition.org/ monderusse/9362 ; DOI : 10.4000/monderusse.9362 


\section{«ДАБЫ РОЗЫСКИ И ПЫТКИ МОГЛИ ЧИНИТЦА ПОРЯДОЧНО, КАК УКАЗЫ ПОВЕЛЕВАЮТ»}

\section{Эволюция теории и практики «розыскного» процесса в России первой половины XVIII в.}

Повседневная практика применения пытки в уголовных процессах российскими судебными учреждениями XVIII в. относится к числу малоизученных тем в современной историографии ${ }^{1}$. С одной стороны, в рамках общей традиции критической оценки степени эффективности судебной системы в России XVIII в. пытка рассматривается как явление незаконное и бесконтрольное. Параллельно ее описание имеет ярко выраженный эмоциональный подтекст, подтверждая тезис о жестокости как характерной черте российского общества. С другой стороны, обозначенная точка зрения во многом строится на выборочном исследовании корпуса, прежде всего, политических процессов ${ }^{2}$ в то время как применение пытки в общеуголовных делах никогда специально не рассматривалось.

Если вопрос об актуальности изучения практики применения пытки в России в первой половине XVIII в. представляется ясным, то выбор теории в качестве предмета для параллельного исследования нуждается в пояснении. В существующей историографии при рассмотрении истории становления

1. В.А. Линовский, Опыт исторических разысканий о следственном уголовном судопроизводстве в России, М., 2001, с. 77-98; А. Циммерман, «Русские пытки. Исторический очерк», Русский архив, год пятый, 1867, стб. 1139-1167.

2. Г.Г. Тельберг, Очерки политического суда и политических преступлений в Московском государстве XVII в., М.,1912, с. 98-108; Н.Б. Голикова, Политические процессы при Петре I, М., 1957, с. 66-67, 116-117; Е.В. Анисимов, Дыға и кнут: Политический сыск и русское общество в ХVIII веке, М.,1999, с. 397-448. 
юридической науки в России основной акцент делается на развитие профильного образования, в первую очередь университетского ${ }^{3}$. Делопроизводство уложенных комиссий 1720-х-1750-х гг. и Сыскного приказа 1730-х-1750-х гг. дает основания предполагать, что в указанный период сформировалась чиновничья прослойка профессионалов-«законоискуссников» ${ }^{4}$, которые не только обладали высоким уровнем знания соответствующего законодательства $^{5}$, но и вырабатывали предложения по его совершенствованию ${ }^{6}$. Их число не было значительно, и, естественно, они не получали юридического образования. В то же время многолетняя правоприменительная практика и/или работа в уложенных комиссиях первой половины XVIII в. ${ }^{7}$ способствовали

3. Г.С. Фельдштейн, Главные течения в истории науки уголовного права в России, М., 2003, с. 3-4, 6-7, 11, 38-40, 46-47 и т.д.

4. В.А. Томсинов, Юридическое образование и юриспруденциия в России в ХVIII столетии, М., 2010, с. 8, 18; Д.О. Серов, Судебная реформа Петра I: Историко-правовое исследование, М., 2009, с. 253-268.

5. Например, в 1741 г. одно из «повытий» Сыскного приказа возглавлял протоколист Петр Донской. Он начал службу в 1714 г. в возрасте 10 лет: сначала служил в Земском приказе, в 1719 г. в должности копииста был переведен в Московский надворный суд, где дослужился до подканцеляриста. В 1727 г. его перевели в Московскую губернскую канцелярию: успехи в расследовании уголовных дел позволили П. Донскому получить должность канцеляриста. В 1730 г. П. Донской перешел в Сыскной приказ, имея 16-летний стаж канцелярской работы, главным образом, с делами уголовного свойства. Поэтому в Сыскном приказе его назначили «править» должность протоколиста. В феврале 1736 г. из Сыскного приказа в Московскую сенатскую контору было подано доношение с просьбой назначить Петра Донского секретарем, поскольку он «к розыскным делам заобычный и секретарем быть достоин». Назначение последовало в 1746 г.: РГАДА (Российский государственный архив древних актов), ф. 248, д. 8122, ч. 3, л. 1032 об.; ф. 372, оп. 1, д. 386, л. 35. В возглавляемое П. Донским «повытье» в 1741 г. входил 17-летний подканцелярист Дмитрий Аверикиев. Он начал служить в Сыскном приказе как пищик в 1739 г. в 15-летнем возрасте. 23 января 1740 г. Д. Аверкиев был приведен к присяге в должность копииста, в том же году его назначили подканцеляристом, а два года спустя (1742) - канцеляристом. В 1746 г. Д. Аверкиев стал секретарем: РГАДА, ф. 248, д. 8122, ч. 3, л. 1033 об. В марте 1745 г. Дмитрий Аверкиев и подканцелярист Алексей Матвеев по требованию Московской сенатской конторы были отправлены в Тайную контору для ведения следствия о раскольниках. В мае того же года прокурор Сыскного приказа Н.С. Безобразов жаловался в Сенат: «когда оные канцелярист и подканцелярист взяты в ту комиссию, на которых почти вся канцелярия и прокурорские дела зависла» и «без оных канцеляриста и подканцеляриста в Сыскном приказе в произвождении дел чинитца крайняя остановка и челобитчикам немалая волокита, а колодникам долговременное задержание»: РГАДА, ф. 372, оп. 1, д. 386, л. 31-32 об.

6. А.С. Замуруев, Работы разных лет, Псков, 2006, с. 190-191. Не высоко оценивая в «О повреждении нравов в России» моральные качества персонального состава и результаты деятельности уложенной комиссии 1754-1766 г., М.М. Щербатов в то же время отмечал знание законов большей частью ее участников: И.И. Дивов - «... наметливый на законы человек»; И.И. Юшков - «...знающий, по крайней мере, российские законы человек», И.Ф. Козлов - «умный и знающий законы человек»: М.М. Щербатов, Избранные труды, сост., автор вступ. ст. и коммент. С.Г. Калинина, М., 2010, с. 459.

7. ПСЗ (Полное собрание законов Российской Империи), т. 5, № 3197, 3201, 3202, 3207, 3463, 4347, 4483; т. 8, № 5287, 5567. В.Н. Латкин, Законодательные комиссии в Pоссии в XVIII в., т. I, СПб.,1887, с. 21-79; C. Peterson, Peter the Great's Administrative and Judicial Reforms: Swedish Antecedents and the Process of Reception, Lund, 1979, p. 340-345; О.А. Омельченко, Кодификация права в России в период абсолютной монархии (вторая половина XVIII века), М., 1989, с. 8-10; Замуруев, Работы разных лет, с. 173-346; 
накоплению значительного объема юридических знаний практического характера и позволяли некоторым из них принимать непосредственное участие в разработке законодательных инициатив ${ }^{8}$. Результатом явился целый ряд значительных по объему уголовно-процессуальных проектов ${ }^{9}$, комплексный анализ которых до сих пор не предпринят.

В этой связи авторы видят свою задачу в том, чтобы попытаться проанализировать «розыскной» процесс в России первой половины XVIII в. с трех точек зрения: законодательной регламентации, законопроектных предложений и практического применения. Причем все указанные позиции рассматриваются взаимосвязано. Как представляется, указанный подход позволит приблизиться к пониманию характера функционирования законодательства в России, степени его реализации на практике, а также влияния последней на процесс законотворчества.

Первая половина XVIII в. выбрана не случайно: как представляется, именно в этот период произошли изменения в области процесса и следствия, результатом которых явилось фактическое устранение пытки из числа следственных методов в России второй половины XVIII в. ${ }^{10}$.

В основе исследования лежат следующие группы источников: 1) законодательство второй половины XVII - первой половины XVIII вв., регулировавшие область использования пытки; 2) делопроизводственная документация и

М.В. Бабич, Государственные учреждения XVIII в., М., 1999, с. 130-133, 215-216, 270-274; Серов, Судебная реформа Петра I, с. 389-399.

8. Томсинов, Юридическое образование и юриспруденция в России в ХVIII столетии, c. 69. Наибольшего внимания в данной связи заслуживает фигура Авраама Степановича Сверчкова (1687 - после 1748). В 1712 г. он был взят в рекруты, служил подьячим в Расправной палате, Земском приказе, в 1718 г. был переведен на ту же должность в Юстиц-коллегию, где к 1712 г. дослужился до должности обер-секретаря. С 1726 г. обер-секретарь Сената, впоследствии статский советник (Д.О. Серов, Администрация Петра I, М., 2007, с. 68). В 19 августа 1720 г. А.С. Сверчков был назначен в канцелярию уложенной комиссии, в деятельности которой принимал самое активное участие (Замуруев, Работы разных лет, с. 21, 28, 33, 34, 35, 104-107, 190, 191, 201 и т.д.). После прекращения заседаний комиссии, Сверчков осуществлял «фактическое руководство канцелярией», при его «активном личном участии в 1724-1725 гг. были изготовлены реестры всех глав и артикулов проекта нового уложения» (Там же, с. 192). По сути, фигура А.С. Сверчкова выступала связующим звеном в работе комиссии 1720-1727 гг. и 1730-1742 гг. (Там же, с. 99-115). Мнение М.В. Бабич о том, что А.С. Сверчков был, «возможно, основным составителем» проектов в комиссии 1720-1727 гг., подтверждается относительно авторства законопроектных разработок в комиссии 1730-1742 гг. (Бабич, Государственные учреждения XVIII в., с. 271) Так, в делопроизводственных материалах, касавшихся проекта «Об удержании пытки в малых делах», составленном А.С. Сверчковым, содержатся следующее замечание: «... по справке при сочинении уложенья о порядке, каким образом в криминальных ... делах поступать назначено быть особливой книге, которая проектами ... обер секретаря Сверчкова готовится: токмо при сочинении уложенья присутствующими еще не слушана, понеже по присланному ис Правительствующаго сената указу велено прежде сочинить судную главу, которая и сочиняется чрез ево Сверчкова проекты» (РГАДА, ф. 342, оп. 1, д. 37, ч. 4, л. 2-2 об.).

9. РГАДА, ф. 342, оп. 1, кн. 33, ч. 1, 2, 3; Там же, д. 37, ч. 4; Проекты Уголовного Уложения. 1754-1766 г2., под ред. А.А. Востокова, пред. Н.Д. Сергеевского, СПБ., 1882.

10. О.А. Омельченко, Власть и закон в России ХVIII века. Исследования и очерки, М., 2004, c. $216-218$. 
законопроекты, составленные в уложенных комиссиях первой половины XVIII в. (прежде всего, в комиссиях 1720-1727 и 1754-1766 гг.); 3 ) делопроизводственные материалы Сыскного приказа, в том числе судебно-следственные процессы 1730-1750-х гг. по двум категориям преступлений (профессиональное воровство и детоубийство), в рамках которых пытке подверглось 80 обвиняемых.

Делопроизводство Сыскного приказа не случайно выбрано для целей данного исследования. С $1730^{11}$ по $1763^{12}$ гг. Сыскной приказ был главной судебной инстанцией по «розыскным» делам в Москве, изъятым из ведения Московской полицмейстерской канцелярии, Московской губернской канцелярии и прочих московских государственных учреждений, которым предписывалось «тех... розыскных дел ничем не ведать», а «которые воры и разбойники пойманы будут в Москве..., тех записав, того ж времени отсылать в Сыскной же приказ» ${ }^{13}$. Находясь под апелляцией Юстиц-коллегии и Сената, с остальными коллегиями Сыскной приказ списывался «промемориями», то есть как с равными себе по статусу. Московской губернской канцелярии он посылал «указы», а от нее получал в ответ «доношения» ${ }^{14}$. По сути, в системе государственных органов Москвы Сыскной приказ занимал положение более высокое, чем главное административное учреждение - Московская губернская канцелярия. Но прежде чем перейти к анализу правоприменительной практики Сыскного приказа необходимо кратко остановиться на определении понятий «розыска» и «пытки».

\section{«Розыск» и пытка в XVIII в.: к определению понятий}

«Розыскные» дела, передаваемые в ведение Сыскного приказа, предполагали использования отдельной формы судопроизводства - «розыска». История «розыскного» процесса выходит за рамки настоящего исследования; отметим только несколько моментов. До 1697 г. в системе судопроизводства в России сосуществовали два вида процесса - суд и сыск/«розыск». Дела, которые решались сыском, не являлись чисто уголовными. Границы между «судом» и «розыском» не совпадали с границами гражданского и уголовного

11. ПСЗ, т. 8, № 5597.

12. ПСЗ, т. 16, № 11989, п. 20.

13. ПСЗ, т. 8, № 5597. О Сыскном приказе см.: Н.Е. Северный, «Описание документов Сыскного приказа 1730-1763 г. Отделение первое. Устройство, состав и делопроизводство Сыскного приказа», в Описание документов и бумаг, хранящихся в Московском архиве министерства юстиции, Спб., 1872, кн. 2; А.А. Голубев, «Сыскной приказ 1730-1763 г. Отделение второе. Содержание документов Сыскного приказа», в Описание документов и бумаг, хранящихся в Московском архиве министерства юстиции, М., 1884, кн. 4; Е.В. Акельев, Повседневная жизнь воровского мира Москвы во времена Ваньки Каина, М., Молодая гвардия, 2012, с. 18-61, 316-373.

14. ПСЗ, т. 16, № 10011. См., например: РГАДА, ф. 372, оп. 1, д. 3359, л. 22, 28. 
судопроизводства по современному праву. Так, к примеру, чисто гражданские крепостные дела решались «розыском» ${ }^{15}$. В соответствии с Соборным уложением посредством «розыска» должны были расследоваться преступления против веры, государства и установленного порядка управления, а также разбой, татьба, кормчество. В 1697 г. суд как отдельная форма возбуждения и проведений следствия был отменен и заменен «розыском» ${ }^{16}$. К 1723 г. относится попытка восстановления состязательных начал в процессе: указ от 5 ноября 1723 г. «О форме суда» предписывал не «различать (как прежде бывало) один суд, другой «розыск», но токмо один суд» ${ }^{17}$. При этом «розыск» не уничтожался ${ }^{18}$. Из-под юрисдикции «суда по форме» изымались все политические дела: «измены, злодейства», слова, «противные на императорское величество и его величества фамилию», бунт ${ }^{19}$. При их решении сохранялись прежние «розыскные» формы судопроизводства. В реальности это изъятие распространялось и на большинство общеуголовных дел, поскольку указом Екатерины I от 3 мая 1725 г. под понятием злодейства помимо вышеперечисленных составов были объединены: богохульство и церковный мятеж, смертоубийство, разбой, кража с поличным ${ }^{20}$.

«Розыскной» процесс был тайным и письменным, при его проведении отсутствовало судоговорение, а поверенные допускались лишь в самых исключительных случаях ${ }^{21}$. Одним из основных следственных методов при «розыске» являлась пытка. Это нашло свое отражение в смысловой двойственности термина «розыск» в России XVII-XVIII вв. С одной стороны, «розыск» означал следственный процесс 22 , а с другой - выступал как синоним

15. М.Ф. Владимирский-Буданов, Обзор истории русского права, Ростов-на-Дону, 1995 , с. 604; В.И. Сыромятников, Очерк истории суда в древней и новой России. Судебная реформа, т. 1, М., 1915, с. 132-134.

16. ПС3, т. 3, № 1572; Владимирский-Буданов, Обзор истории русского права, с. 610.

17. ПС3, т. 7, № 4344 .

18. Ф.М. Дмитриев, История судебных инстанций и гражданского апелляционного судопроизводства от Судебников до Учреждения о губерниях, М., 1859, с. 538-539; Сыромятников, Очерк истории суда в древней и новой России, с. 172-175; К.Д. Кавелин, Собрание сочинений, т. 4. СПб., 1898, стб. 404-410; Владимирский-Буданов, Обзор истории русского права, с. 612; Peterson, Peter the Great's Administrative and Judicial Reforms, p. 334-336, 345-353; Российское законодательство Х-ХХ вв., т. 4, М., 1986, c. 394-396; О.И. Чистяков, «Процессуальное законодательство», Законодательство Петра I, М., 1997, с. 793-821; О.Е. Кутафин, В.М. Лебедев, Г.Ю. Семигин, Судебная власть в России, т. II, М., 2003, с. 145-150, 818; А.И. Александров, Уголовная политика и уголовный процесс в Российской государственности: история, современность, перспективы, проблемы, СПб., 2003, с. 128-172; М.О. Акишин, «Судоустройство и судопроизводство в Сибири в 1727 - начале 1780-х гг. (к постановке проблемы)», Государственные реформы М.М. Сперанского в исторической ретроспективе. Материаль конференции 30 сентября - 1 октября 2004 г., Новосибирск, 2005, с. 91-92, 96-97; Серов, Судебная реформа Петра I, с. 95, 335-338.

19. ПСЗ, т. 7 , № 4344, п. 5.

20. ПСЗ, т. 7, № 4713 .

21. Владимирский-Буданов, Обзор истории русского права, с. 611.

22. Кутафин, Лебедев, Семигин, Судебная власть в России, с. 796-797. 
пытки. «Криминальные», «розыскные» и «пыточные» дела фигурировали как синонимы в названии второй книги проекта, составленного уложенной комиссией 1720-1727 гг. ${ }^{23}$ В пояснительной записке 1739 г. к проекту оберсекретаря Сената Авраама Степановича Сверчкова «Об удержании пытки в малых делах» фиксируется та же синонимичность: криминальные дела есть «розыскные и пыточные» ${ }^{24}$. «Словарь Академии Российской» в качестве второго значения термина «розыск» приводит «пыточный допрос, пристрастный допрос, пытка» ${ }^{25}$. Делопроизводственный язык Сыскного приказа подтверждает смысловую тождественность понятий «розыск» и «пытка». Принятие решения о пытке подозреваемого могла сопровождать секретарская помета «к розыску» ${ }^{26}$. «Розыск» и «пытка» употреблялись как синонимы в пыточных протоколах при указании присутствовавших при пытке членов Сыскного приказа («при том розыске были...») или характера данных показаний («а с подъему и с третьяго розыску ... [показал] то ж, что в роспросе и $з$ дву розысков» $\left.{ }^{27}\right)$.

В российском законодательстве XVII-XVIII вв. отсутствовало какое-либо определение того, что есть пытка. Как в 1738 г. в примечаниях к «Русской правде» отмечал Василий Никитич Татищев, «у нас о пытке ясного закона нет» ${ }^{28}$. Первая попытка ее дефиниции присутствует во второй книге проекта «О процессе в криминальных, или розыскных, пыточных делах», составленном в уложенной комиссии 1720-1727 гг. Практически дословно воспроизводя 1 и 2 статьи «швецкого процессу 2 главы», составители уложения указывали, что «тортура или пытка, хотя оная телу весьма чувствительное оскорбление причиняет» есть средство, изобретенное «для изпытания и изведывания правды». Она используется «за неимением обличения противу злых и хитрых людей» с тем, чтобы «принудить» их к открытию «правды», однако только в том случае, когда «оную иным способом испытать невозможно» ${ }^{29}$, и есть веские «причины и совершенное подозрение» ${ }^{30}$. Законопроект уложенной комиссии 1754-1766 гг. «О розыскных делах и какие за разные злодейства и преступления казни, наказания и штрафы положены» более лаконичен: пытка мыслится как «чрезвычайное средство к сысканию истины», к которому нельзя прибегать «без крайней нужды» ${ }^{31}$. При этом оба проекта настоятельно

23. РГАДА, ф. 342, оп. 1, кн. 33, ч. 2.

24. РГАДА, ф. 342, оп. 1, д. 37, ч. 4, л. 2.

25. Первое значение «розыска» - «прилежное разобрание, изследование, испытание истины, точности в чем»: Словарь Академии Российской, производным порядком расположенный, ч. V. СПб., 1793. Стб. 1069.

26. См., например: РГАДА, ф. 372, оп. 1, ч. 2, д. 6210, л. 109-123 об.

27. См.: РГАДА, ф. 372, оп. 1, д. 481, л. 6 об., 9, 9 а; д. 957, л. 14, 21; оп. 1, д. 1440, л. 25-26.

28. Цит. по: Анисимов, Дыба и кнут, с. 440.

29. РГАДА, ф. 342, оп. 1, кн. 33, ч. 2, л. 154, 160,164.

30. РГАДА, ф. 342, оп. 1, кн. 33, ч. 2, л. 24.

31. Проекты Уголовного Уложения, с. 27. 
подчеркивали тот факт, «что пыткою поступать не надлежит» до проведения предварительных следственных действий ${ }^{32}$.

Итак, прерогатива на исключительное расследование «розыскных» дел (т.е. «татиных, и разбойных, и убивственных» ${ }^{33}$ ) по сути означала, что в Москве только Сыскной приказ имел право использовать пытку как следственный метод.

\section{Повседневная практика применения пытки в Сыскном приказе}

Судебно-следственная практика Сыскного приказа 1730-х-1750-х гг. в делах об имущественных преступлениях и детоубийстве позволяет установить, во-первых, место пытки в «розыскном» процессе, а во-вторых, законодательные источники, de facto регулировавшие порядок ее применения.

Расследование преступления никогда не начиналось с пытки подозреваемого. Вне зависимости от того, по чьей инициативе было возбуждено дело $^{34}$, пытке предшествовал ряд следственных мероприятий, по результатам которых Сыскной приказ выносил определение о ее применении. Алгоритм расследования преступления и принятия решения о пытке был тождественен во всех случаях и не зависел от источника возбуждения дела. После получения явочной челобитной или доношения с мест дело передавалось для расследования в повытье ${ }^{35}$, а представленный при нем подозреваемый отдавался под караул. После этого подследственный допрашивался, а данные им при «расспросе» показания выступали в качестве основания для приговора о пытке. Так, 19 ноября 1750 г. было начато дело по челобитной служителя князя Федора Ивановича Голицына Козьмы Баженова, при котором в Сыскной приказ была представлена дворовая Арина Федорова, подозревавшаяся в убийстве незаконнорожденного ею ребенка ${ }^{36}$. Помета на челобитной указывает, что она была «взята в повытье», а само дело находилась «в произвождении в должности секретаря протоколиста Петра Донского»и

32. РГАДА, ф. 342, оп. 1, кн. 33, ч. 2, л. 154; Проекть Уголовного уложения, с. 27.

33. ПСЗ, т. 8, № 5597.

34. Как показывает сплошной просмотр протокольных книг Сыскного приказа за 1742 г., из 773 дел 33\% были возбуждены по промемориям из других учреждений, 27,2\% - по челобитным душевладельцев (помещики, монастырские стряпчие), 7,2\% - по прочим челобитным, 32,6\% - по инициативе Сыскного приказа (из них 188 касалось внутреннего управления): РГАДА. ф. 372, оп. 2, д. 113-124.

35. Вся канцелярия Сыскного приказа подразделялась на шесть повытий (т.е. отделов), между которыми и распределялись дела. Служащие одного повытья (обычно 2 - 5 человек: канцелярист, подканцелярист и 1 - 3 копииста). Работу каждого повытья курировали секретари, которые заседали в отдельной «секретарской» палате за большим секретарским столом. Секретари должны были контролировать делопроизводственный процесс и в присутственные дни ходить в судейскую с докладами по текущим делам: Акельев, Повседневная жизнь воровского мира Москвы во времена Ваньки Каина, с. 32-61.

36. РГАДА, ф. 372, оп. 1, д. 2409, л. 1. 
«канцеляриста Семена Стрелкова» ${ }^{37}$. В той же помете указывалось, чтоб «приводную девку в Сыскной приказ принять и отдать под караул, и против сего челобитья оную девку расспросить и, выписав из указов, доложить немедленно» ${ }^{38}$. Арина Федорова была допрошена, а затем «расспросные речи» были ей зачитаны в присутствии судей надворного советника Осипа Засецкого и коллежского асессора князя Михаила Вадбольского и «по ее прошению» подписаны «Сыскного приказу бывшим копиистом Василием Суворовым» ${ }^{39}$. 13 декабря 1750 г. «за скрепою Сыскного приказа господ присудствующих Александра Коротнева, Осипа Засецкого, княз Михаила Вадболского, в должности секретаря протоколиста Петра Донского» на основании «расспросных речей» было вынесено решение «пытать и спрашивать ее Ирину, что она Ирина подлинно ль родила мертвого и для чего того мертвого младенца тело кинула в нужник» ${ }^{40}$.

Механизм начала следствия и вынесения решения о пытке был идентичным и в делах против профессиональных воров, возбужденных «по извету» известного доносителя Ивана Осипова Каина, а также поступавших в Сыскной приказ из других государственных учреждений. Так, арестованные И. Каином 27 февраля 1746 г. беглые солдаты Иван Стромынский и Савелий Исаев, беглый фабричный Никифор Суета и укрывавший их в своем доме крестьянин Григорий Борсукова были допрошены в Сыскном приказе, признались в соучастии в разбоях на подмосковных дорогах ${ }^{41}$, и на следующий день, 28 февраля, были приговорены к пытке ${ }^{42}$.

Отметим, что практика пыточного процесса находилась в рамках закона: каждому случаю использования пытки предшествовало коллективное судейское решение, выносимое на основе законодательства, статьи которого заносились в протокол после перечисления обстоятельств дела. Выписки из законов («к сему делу из указов выписки») предшествовали тексту постановления ${ }^{43}$. Основным законодательным источником процессуальной практики Сыскного приказа в делах об имущественных преступлениях и детоубийстве выступало Соборное уложение, которое дополнялось ссылками на узкий круг законов. В известных нам случаях выписывались следующие указы:

разбоя - 16, 58 и 63 статьи 21 главы Соборного Уложения;

37. РГАДА, ф. 372, оп. 1, д. 2409, л. 1a, 1 об.

38. РГАДА, ф. 372, оп. 1, д. 2409, л. 1 об.-2.

39. РГАДА, ф. 372, оп. 1, д. 2409, л. 3 об.

40. РГАДА, ф. 372, оп. 1, д. 2409, л. 8-8 об.

41. РГАДА, ф. 372, оп. 1, д. 1440, л. 32-46 об.

42. «ОПРЕДЕЛИЛИ: вышеписанных разбойников Савелья Исаева, Ивана Стромынского, ... Никифора Суету ... по повинкам их в разбоях и в других воровствах пытать, и на кого будут показывать оговор, тех сыскивать и роспрашивать, и в чем учинится спор, давать очные ставки» (РГАДА, ф. 372, оп. 1, д. 1440, л. 53 -53 об.).

43. РГАДА, ф. 372, оп. 1, д. 809, л. 7 об.; д. 957, л. 10 об.; д. 1271, л. 4; д. 1607, л. 4; д. 2409, л. 7-7 об.; д. 2587, л. 3. 
карманных краж и мелкого воровства - 9, 40, 50, 58, 63, 64 статьи 21 главы Соборного Уложения; указ от 5 марта 1731 г.;

покупки и хранения краденного - 9, 11, 15, 32, 58, 63, 64 статьи 21 главы Соборного Уложения; указ от 5 марта 1731 г.;

воровства и пристанодержательства - 5, 8, 9, 11, 15, 64 пункты 21 главы Соборного Уложения и 4 пункт указа от 24 декабря 1719 г.;

детоубийства - 8, 9, 26, 48, 58, 63, 69 статьи 21 и 3, 26 статья 22 главы Соборного Уложения; 103 артикул и толкование 19 главы и 169, 176 артикул и толкование 20 главы Воинского устава; «статьи писцового наказа 193 и 194 годов» ${ }^{44}$; указ 5 марта 1731 г., «указ 165 году» $(1656 / 57 \text { г. })^{45}$ (более подробно речь пойдет о нем ниже), «Кормчая книга правило с(вят)аго Василия Великого 33 лист $236 »^{46}$.

Законодательные источники определений о пытке были схожи, но не идентичны в однотипных делах. Так, в одном случае (1741 г.) решение о пытке по подозрению «в мошенничестве» (карманные кражи, кражи с повозок, кражи в банях) было вынесено на основании 9, 50, 58, 63 и 64 статей 21 главы Соборного уложения и указа от 5 марта $1731 \Gamma^{47}$, в другом (1746 г.) - 9, 40, 58, 64 пунктов той же главы ${ }^{48}$. В расследовавшихся во второй половине 1738 г. двух делах по подозрению в детоубийстве пытка применялась в первом случае на основании 48 и 58 статей 21 главы и 26 статьи 22 главы Соборного уложения, а во втором случае - на основании той же 26 статьи 22 главы Соборного уложения и 176 артикула и толкования 20 главы Воинского устава ${ }^{49}$. Как представляется, с одной стороны, фиксируемая ситуация могла быть следствием различности конкретных обстоятельств дела, а с другой - проистекала из особенностей правоприменения в России XVIII в. (более подробно речь об этом пойдет ниже).

В целом набор указов, которыми оперировали члены Сыскного приказа, был меньше того, который действовал в законодательстве первой половины XVIII в. Материалы уложенных комиссии 1730-1742 и 1754-1766 гг,, а также документы, примыкающие к «Обряду как обвиненный пытается» (составлен не ранее 1763 г.) дают возможность очертить круг законов, определявших сферу применения пытки в первой половине XVIII в. ${ }^{50}$

44. «Велено которые помещики и вотчинники и люди их у кого на чужей земли учинили смертное убивство, и про том убивство розыскивать всякими сыски накрепко, и давать очные ставки» (РГАДА, ф. 372, оп. 1, д. 6064, л. 4).

45. РГАДА, ф. 372, оп. 1, д. 1271, л. 4.

46. «Жена аще на пути родит, и о рождшемся отрочати не брегуще, оставитье, убивства греху повинна есть» (РГАДА, ф. 372, оп. 1, д. 721, л. 4.)

47. РГАДА, ф. 372, оп. 2, д. 113, л. 81; Оп. 1, д. 1534, л. 21-22 об.

48. РГАДА, ф. 372, оп. 1, д. 1534, л. 21-22 об.

49. РГАДА, ф. 372, оп. 1, д. 481, л. 5; д. 497, л. 6.

50. Во всех случаях - это экстракты из действующего законодательства. В комиссии 1730-1742 гг. они были сделаны во исполнение сенатского постановления от 18 сентября 1738 г., которое, ссылаясь на указ Петра I от 6 апреля 1722 г., предписывало «о удержании 
Большая часть выписок из законодательства была сделана из Соборного уложения ${ }^{51}$ и Новоуказных статей ${ }^{52}$. К ним примыкали:

\begin{tabular}{|c|c|}
\hline Комиссия 1730-1742 гг. & $\begin{array}{l}\text { Указы от «191 году марта } 11 \text { дня» }{ }^{53}, \text { «195 года марта } 11 »^{54} \text {, } \\
28 \text { ноября } 1687 \text { г.55 }^{55}, 16 \text { февраля } 1700 \text { г. }^{56}, \\
10 \text { марта } 1702 \text { г. }^{57}, 18 \text { июля } 1726 \text { г. }{ }^{58} .\end{array}$ \\
\hline Комиссия 1754-1766 гг. & 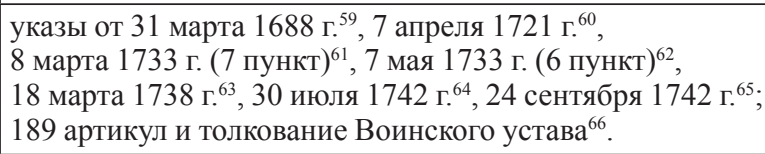 \\
\hline $\begin{array}{l}\text { «Обряд как обвиненный } \\
\text { пытается» }\end{array}$ & $\begin{array}{l}\text { «указ } 182 \text { году» }{ }^{67} \text {, «указ } 197 \text { году» }{ }^{68} \text {, } \\
\text { указ } 12 \text { ноября } 1721 \text { г. }^{69} .\end{array}$ \\
\hline
\end{tabular}

Указы, общие для трех источников, кроме Соборного Уложения и Новоуказных статей: 24 декабря 1719 г. («для сыску воров и разбойникам афицерам

в малых делах пыток» сочинить «проект» и «приложить к докладу» (РГАДА, ф. 342, оп. 1, д. 37, ч. 4, л. 35). В елизаветинской комиссии - предназначались «по плану 2-ой части к 7-ой главе» «О пытке» и 8-ой главе «По каким подозрениям пытать, в том числе оговорных и ополиченных» (РГАДА, ф. 342, оп. 1, д. 58, тетрадь 4, 8). В приложении к «Обряду...» поясняли, «по законам в чем и кого и как пытать велено» (РГАДА, ф. 7, оп. 2, д. 2116.).

51. РГАДА, ф. 342, оп. 1, д. 37, ч. 4, л. 35-37; д. 58, тетрадь 4, л. 1-13; тетрадь 8, л. 1-4 об.; ф. 7, оп. 2, д. 2116, л. 4-4 об., 6-7 об., 9-12 об.

52. РГАДА, ф. 7, оп. 2, д. 2116, л. 12; ф. 342, оп. 1, д. 37, ч. 4, л. 35 об., 36 об.-37; д. 58, тетрадь 4 , л. 13 об.-18.

53. РГАДА, ф. 342, оп. 1, д. 37, ч. 4, л. 37.

54. РГАДА, ф. 342, оп. 1, д. 37, ч. 4, л. 40-40 об.

55. РГАДА, ф. 342, оп. 1, д. 37, ч. 4, л. 42-42 об.

56. РГАДА, ф. 342, оп. 1, д. 37, ч. 4, л. 41.

57. РГАДА, ф. 342, оп. 1, д. 37, ч. 4, л. 43.

58. РГАДА, ф. 342, оп. 1, д. 37, ч. 4, л. 44.

59. РГАДА, ф. 342, оп. 1 , д. 58, тетрадь 4, л. 18 ; отсутствует в ПСЗ.

60. РГАДА, ф. 342, оп. 1, д. 58, тетрадь 8, л. 7 об.; отсутствует в ПСЗ.

61. РГАДА, ф. 342, оп. 1, д. 58, тетрадь 4, л. 19. об.; Тетрадь 8, л. 8-8 об.; отсутствует в ПСЗ.

62. РГАДА, ф. 342, оп. 1, д. 58, тетрадь 8, л. 10 об.-11; ПСЗ, т. 9, № 6391.

63. РГАДА, ф. 342, оп. 1, д. 58, тетрадь 8 , л. 8 об.

64. РГАДА, ф. 342, оп. 1, д. 58, тетрадь 8, л. 9-10 об.; ПСЗ, т. 11, № 8601.

65. РГАДА, ф. 342, оп. 1, д. 58, тетрадь 8, л. 9; ПС3, т. 11, № 8611.

66. РГАДА, ф. 342, оп. 1, д. 58, тетрадь 8, л. 4 об.

67. РГАДА, ф. 7, оп. 2, д. 2116, л. 4, 4 об.-5; ПСЗ, т. 1, № 561.

68. РГАДА, ф. 7, оп. 2, д. 2116, л. 4. Отметим, что целый ряд указов (до 1754 г.), включенных в ПСЗ как относящиеся к пытке, не вошел в выписки комиссии.

69. РГАДА, ф. 7, оп. 2, д. 2116, л. 4 об., 6 об., 9. 
инструкция») $)^{70}, 6$ апреля 1722 г. $^{71}$, сентябрь ${ }^{72} / 24$ октября 1726 г. $^{73}, 1-10$ пункты 6 главы «Краткого изображения процессов» ${ }^{74}$.

Таким образом, во-первых, приоритетное использование Соборного уложения как источника процессуальных постановлений в Сыскном приказе в целом находилось в русле законодательной традиции первой половины XVIII в., во-вторых, в рассматриваемых нами делах в качестве источников права не выступали Новоуказные статьи и «Краткое изображение процессов ${ }^{75}$. Недействующими оказывался и целый ряд указов, которые фигурируют в выписках комиссий, общей характерной чертой которых была нацеленность на четкое установление категорий дел и подозреваемых, подлежащих пытке ${ }^{76}$. Подчеркнем, что этот факт не может быть объяснен тем, что какие-то действующие законодательные постановления не были доступны служащим Сыскного приказа. На самом деле, они имели доступ практически ко всем публиковавшимся законодательным актам. В 1730 г., в год учреждения Сыскного приказа, одним из пунктов расхода денежных средств была закупка указных книг. Тогда в Московской сенатской типографии Сыскной приказ были приобретены сборники указов 1714-1719, 1727 и 1728 гг. «пункты о наследстве» 1725 г. и «Устав о купечестве» 1727 г., Генеральный регламент,

70. РГАДА, ф. 7, оп. 2, д. 2116, л. 9; ф. 342, оп. 1, д. 58, тетрадь 4, л. 18 об.; ПС3, т. 5, № 3477 .

71. РГАДА, ф. 7, оп. 2, д. 2116, л. 6; ф. 342, оп. 1, д. 58, тетрадь 8, л. 7 об.; ПС3, т. 6, № 3933 .

72. РГАДА, ф. 7, оп. 2, д. 2116, л. 6 об.

73. РГАДА, ф. 342, оп. 1, д. 58, тетрадь 8 , л. 7 об.

74. РГАДА, ф. 7, оп. 2, д. 2116, л. 6 об., 7 об. $-8,9$ об., 11; ф. 342, оп. 1, д. 58, тетрадь 8 , л. $5-7$.

75. Авторы сознательно отстраняются от дискуссии по вопросу о «Кратком изображении процессов» как источнике права в общеуголовных делах по нескольким причинам. Во-первых, в существующей историографии наблюдения о характере использования воинских процессов за редким исключением основаны на изучении законодательства, но не судебной практики. В последнем случае имеющиеся данные явно недостаточны для заключений более общего порядка. С определенной долей уверенности можно утверждать, что во второй половине $1750-$ х - начале 1760-х гг. «Краткое изображение..» (прежде всего, 10 пункт 6 главы) были основанием при разбирательстве дел, в которых субъектами преступления являлись несовершеннолетние. Во-вторых, подготовительные материалы проектов по обновлению уголовного права и процесса, составленные в уложенной комиссии 1720-1727 и 1754-1766 гг, свидетельствуют о том, что «воинские процессы» воспринимались как действующий процессуальный источник. В-третьих, как представляется, в судопроизводственной практике соотношение гражданского и военного законодательства могло регулироваться принципом, в 1765 г. изложенным Сенатом: «ныне чего в военных процессах не достает, одолживаются гражданскими правилами, а чего в гражданских недостаточно, то заимствуют из военных процессов» (РГАДА, ф. 342, оп. 1, д. 65, ч. 5, л. 48).

76. Проекты уложенных комиссий 1720-1727 и 1754-1766 г. предлагали регулировать тот же спектр вопросов. Это, в частности, подтверждает структура проекта «О процессе в криминальных или розыскных и пыточных делах». Из 12 глав, которые должны были составить проект, 8 касались категорий дел и подозреваемых, а также признаков, на основании которых могла налагаться пытка (См.: РГАДА, ф. 342, оп. 1, кн. 33, ч. 2, л. 90 об.- 399 об.; Зумуруев, Работы разных лет, с. 204-205). 
Адмиралтейский устав, «плакат», губернаторскую инструкцию, один экземпляр печатного Соборного уложения и Новоуказных статей, Военный устав. Всего в 1730 г. Сыскной приказ на указные книги потратил 22 рубля 85 копеек $^{77}$. В дальнейшем все публиковавшиеся указы присылались в Сыскной приказ, которые после обязательного ознакомления с ними служащих, подшивались в книги. Опись документов, уцелевших во время пожара 29 мая 1737 г., позволяет восстановить перечень «указных книг», находившихся в Сыскном приказе. Среди них были основные - печатное Соборное уложение 1649 г.; печатная Кормчая книга 1650 г.; рукописный сборник Новоуказных статей 1669 г.; печатный сборник указов с 1714 по 1719 год; рукописная книга присылаемым указам и ведениям о различных делах 1718 г.; печатный Воинский устав и Артикул воинский; печатные сборники петровских указов с 1719 по 1720; печатный Генеральный регламент 1720 г.; печатный Регламент Адмиралтейский; печатный сборник указам 1721 г.; печатный Духовный регламент 1721 г.; печатная книга, «называемая Плакат» 1724 г;; печатная книга «о наследствии» 1725 г.; печатные книги указов 1727 и 1728 г; п печатная книга, называемая «Устав о купечестве» 1728 г.; печатная «инструкция губернаторская и воеводцкая и товарищем их» 1728 г; рукописная книга присылаемых указов и промеморий 1730, 1731, 1735 годов $^{78}$.

Резонен вопрос, почему в таком случае ряд действующих законов о пытке не применялся на практике? Изучение правоприменительной практики Сыскного приказа показало, что при значительном количестве дополнявших друг друга (а иногда и вступавших в противоречие) законодательных актов, а также нечеткости формулировок ${ }^{79}$ в судебно-следственных органах складывалась прецедентная практика использования того или иного указа. Это не означало, что прецедент являлся источником права: скорее, он выступал «формою права эпохи» ${ }^{80}$, когда одно и то же повытье или один и тот же служащий Сыскного приказа апеллировали к устоявшемуся кругу законодательных источников при вынесении решений по схожим делам. Практика использования законов канцелярскими служащими Сыскного приказа 30 50-х гг. XVIII в. могла быть подобна той, которую описывал Михаил Александрович Дмитриев, служивший судьей в 1825-1833 гг.: «Что касается до законов уголовных, относящихся как до следствия, так и до решения дел, напрасно думают, что до издания Свода трудно было узнать их. Их было не так много, как воображают, ибо из всей кипы старых законов в ходу были немногие. Из всего «Уложения» царя Алексея Михайловича нужна

77. РГАДА, ф. 372, оп. 1, д. 3, л. 7-9, 14, 29, 46.

78. РГАДА, ф. 248, д. 1649, л. 59-66; см. также: РГАДА, ф. 372, оп. 1, д. 2919, л. 3.

79. На целый ряд пробелов и не «доволного изъяснения» законодательства указывал в проекте «Об удержании пыток в малых делах» А.С Сверчков, констатируя, что судья «мог разно ... толковать» и применять на практике действующие законы: РГАДА, ф. 342, оп. 1, д. 37, ч. 4, л. 2 об. -4 об., 9-9 об.

80. Омельченко, Власть и закон, с. 292. 
была только 10-я глава, потом - для следствия - «Воинские процессы Петра Великого», а для решения дел «Воинские артикулы», отчасти Воинский и Морской уставы. Из всех названных мною томов применялись только несколько пунктов, которые мы знали наизусть... Потом манифест Екатерины, кажется, 1784 года, разделяющий воровство на четыре степени: разбой, грабеж, кража и мошенничество; и знаменитый ее же манифест 1787 года о спокойствии, или о поединках. Две-три статьи Наказа и немногие законы Александра: вот и все» ${ }^{81}$.

При этом еще раз подчеркнем - само решение о применении пытки всегда основывалось на законе, волюнтаристские постановление преследовались, а незаконное применение пытки строго пресекалось. Так, в сентябре 1736 г. присутствующие Сыскного приказа действительный статский советник Алексей Зыбин, майор Степан Ступишин и «секретарь, который то дело производил», за необоснованное наложение пытки на Ивана Куимова, «работника» московского купца Никиты Луковникова, были наказаны понижениями в чинах и крупными денежными штрафами (500 и 200 руб.). В приговоре указывалось, что вышеназванные члены Сыскного приказа действовали «в противность уложенной 21 главы, 54 п. и указов» ${ }^{82}$. Вопрос о том, на основании каких указов было вынесено постановление, требует дальнейшего изучения, однако отметим, что в законодательстве только «Краткое изображение процессов» предусматривало ответственность за неправомочную пытку. В соответствии с 4 пунктом 6 главы в зависимости от степени умысла при вынесении подобного решения на судью мог налагаться штраф, наказание «по присуждению вышнего судьи» и даже смертная казнь $^{83}$. Практически без изменений этот же пункт «воинских процессов» лег в основание 2 артикула 9 главы «Как должен судья осторожно в пытках поступать» проекта комиссии 1720-1727 гг. «О процессе в криминальных или розыскных и пыточных делах» ${ }^{84}$. Отдельные санкции за пытку не по законам предлагались и в составленной в той же комиссии «книге первой» «Уложения Российского государства» - «О процессе, то есть о суде, месте и о лицах, к суду подлежащих». 47 пункт 4 главы «О судьях и качестве и должности их» полагал возможным «учинить судье тож» и «доправить истязанному бесчестье втрое» ${ }^{85}$.

Особое стремление предать пытке по общеуголовным делам в Москве строго законный характер обнаружилось в апреле 1733 г., когда над Сыскным приказом был установлен прокурорский надзор, «дабы розыски и пытки могли чинитца порядочно, как указы повелевают, без напрасного невинным

81. М.А. Дмитриев, Главы из воспоминаний моей жизни, М., 1998, с. 287-288.

82. Северный, «Описание документов Сыскного приказа 1730-1763 гг. ...», с. 133.

83. ПСЗ, т. 5, № 3006, с. 404-405.

84. РГАДА, ф. 342, оп. 1, кн. 33, ч. 2, л. 365-366.

85. РГАДА, ф. 342, оп. 1, кн. 33, ч. 2, л. 358 об. 
мучения и кровопролития» ${ }^{86}$. Надзорная деятельность прокуроров Сыскного приказа над всею процедурою судопроизводства способствовала оптимизации процесса следствия и сопровождающей его документации. Так, с 1744 г. по инициативе прокурора Сыскного приказа Никиты Семеновича Безобразова обязательным стал факт подписи судьями расспросных речей колодников «по прочтении их» ${ }^{87}$. За два года до этого, в сентябре 1742 г., предложение того же прокурора Н.С. Безобразова на имя генерал-прокурора легло в основу сенатского указа, регулировавшего принципы оформления так называемых «пыточных речей». Этот сюжет заслуживает специального рассмотрения, так как позволяет выйти на серьезную проблему влияния правоприменительной практики на процесс усовершенствования процессуального законодательства в России первой половины XVIII в.

\section{Влияние практики «розыскного» процесса на законодательство}

«Пыточные речи» - единственный источник, дающий информацию о «технологии» пытки в повседневной процессуальной практике по общеуголовным делам. В Сыскном приказе существовал достаточно устойчивый формуляр «пыточных речей»:

1) Преамбула, в которой после обозначения даты и выражения «по вышеписанному... определению» (т.е. по такому-то решению Сыскного приказа о пытке) следовало указание на действия, предпринимавшиеся в отношении подозреваемого (такой-то был «привожен» или «взят в застенок», «поднят на виску» и «пытан» с указание порядкового номера пытки $)^{88}$. В 1750-х гг. вступительная часть протокола становится более лаконичной: отмечается дата, содержится ссылка на «определение», фиксируется имя и пишется «пытан» ${ }^{89}$.

2) Далее следует основная часть, собственно «пыточные речи», или показания, которые были даны подследственным под пыткой.

3) В заключительной части обозначается, какому физическому воздействию был подвергнут обвиняемый (как правило, число ударов кнутом; в исключительных случаях - пытка огнем), а затем перечисляются «присутствующие» Сыскного приказа, бывшие при пытке.

На каждую из пыток составлялся отдельный протокол. В изученных нами делах четкое указание на количество пыток, которым надлежало подвергнуть подозреваемого, присутствует только в 2 случаях, когда во время допроса колодник менял показания. «Переменные речи» со ссылкой на «указ

86. Северный, «Описание документов Сыскного приказа 1730-1763 гг. ...», с. 132.

87. Северный, «Описание документов Сыскного приказа 1730-1763 гг. ...», с. 190.

88. См., например: РГАДА, ф. 372, оп. 1, д. 481, л. 7, 10, 10 а; Оп. 1, д. 1534, л. 23 и т.д.

89. «1753 году маия 11 дня по силе вышеписанного определения содержащаяся женка Домна Назарьева в умерщвлении младенца пытана впервые» (РГАДА, ф. 372, оп. 1, д. 5516, л. 7; см. также: д. 2409, л. 9). 
165 года» $(1656 / 57 \text { г. })^{90}$ служили основанием для вынесения приговора о 3 -кратной пытке и «зжении огнем» ${ }^{91}$. Остальные определения давали очень общее предписание - «пытать и при пытке спрашивать». Последнее подразумевало выяснение обстоятельств дела, соучастников и возможных фактов участия в других преступлениях ${ }^{92}$. Четких сроков, устанавливавших время между принятием решения о пытке (оно записывалось в «журнал», а копия включалась в дело) и самим действием пытки, не существовало. Подследственный мог быть пытан в день вынесения определения, а мог ожидать его приведения в исполнение более месяца.

«Пыточные» протоколы не фиксировали «живую речь» колодника, а были продуктом приказного делопроизводства: в них не заносились вопросы, задававшиеся обвиняемому, а ответы приводились, кратко на уровне пересказа. Вопросы составлялись «с подлинных речей», т.е. тех показаний, которые преступники давали на допросах. Поэтому очень часто информация расспросов и пыточных речей оказывалась почти идентичной ${ }^{93}$. Вероятно, подобная ситуация была полем для злоупотреблений, поскольку «для лакомства» и «от неполучения жалованья» ${ }^{94}$ низшие служащие приказа могли менять содержание «речей», «закрывая винных». Последний факт и стал причиной обращения прокурора Сыскного приказа Н.С. Безобразова в Сенат в 1742 г. В результате сенатского постановления от 1 сентября 1742 г. судьи Сыскного приказа обязаны были подписывать черновые «пыточные речи [...] не выходя из застенка, а беловые по выполнении оных» ${ }^{95}$. В Сыскном приказе указ сразу был принят к исполнению, и в ряде дел, действительно, появляются и черновые, и беловые пыточные протоколы, подписанные

90. «... Которые воры, тати и разбойники в городех в распросех говорят сами на себя и на товарищей своих во многих воровствах и после того взяты будут к Москве, и на Москве в роспрсех и с пыток с себя и с товарищей своих зговаривают и скажут, что они на себя и на товарищей своих показывали напрасно, и тех воров и с переменных речей пытать трижды и огнем жечь и верить тем речам, что они на Москве с пыток и с огня учнут говорить» (РГАДА, ф. 372, оп. 1, д. 1271, л. 5-6; ч. 1, д. 1534, л. 27об.). Данный указ отсутствует в ПСЗ. Полный текст см.: РГАДА, ф. 342, оп. 1, кн. 33, ч. 2, л. 59).

91. РГАДА, ф. 372, оп. 1, д. 1534, л. 24-25 об., 27 об. и далее; оп. 1, д. 1271, л. 3-9.

92. Например: «...пытать и при пытке спрашивать, кто еще у себя таких же мошенников держали, и что у них покупали, и кому ис тех краденых вещей продавали, и на кого будут показывать, тех оговорных сыскивая, роспрашивать и в спорных речах давать очные ставки» (РГАДА, ф. 372, оп. 2, д. 113, л. 3-11 об.).

93. См.: РГАДА, ф. 372, оп. 1, д. 481, л. 7, 10, 10 а; оп. 1, д. 537, л. 7-9; д. 3275, л. 6; д. 6064. л. 6 об., 7, 7 об.; оп. 1, д. 1440. л. 25-26, 55-57 и т.д.

94. Начиная с указа от 23 мая 1726 года приказным служителям, производящие дела, не выдавалось жалованья: они должны были «довольствоваться от дел... с челобитчиков, кто что даст по своей воле» (ПСЗ, т. 7, № 4889, с. 652-653). Из приходо-расходных книг Сыскного приказа видно, что жалованье получали и судьи, и заплечные мастера, и сторожа, и прикрепленный священник. Но секретари, канцеляристы, подканцеляристы и копиисты не получали ни копейки вплоть до 1750 г. (Акельев, Повседневная жизнь воровского мира Москвы во времена Ваньки Каина, с. 53).

95. ПСЗ, т. 11, № 8611. 
присутствующими приказа ${ }^{96}$. Однако, это никак не повлияло на характер регистрации показаний (она все также оставалась пересказом), а при переписывании набело редактирования практически не производилось: беловые протоколы почти всегда повторяли черновые, а разночтения могли объясняться обращением следователей к «роспросам» колодников.

\begin{tabular}{|l|l|}
\hline \multicolumn{1}{|c|}{ Черновой протокол } & \multicolumn{1}{|c|}{ Беловой протокол } \\
\hline «1751 году генваря 11-го дня по & «1751 году генваря 11-го дня по \\
вышеписанному определению & вышеписанному определению \\
означенная девка Ирина Федорова дочь & означенная девка Ирина Федорова дочь \\
взята в застенок и пытана в первой. & взята в застенок и пытана впервые. \\
А с первой пытки она Ирина показала & А с первой пытки она Ирина показала \\
то ж, что и в роспросе своем говорила, & то ж, что и в роспросе своем говорила, \\
что де господина ея княз Федор княж & что де господина ея княз Федор княж \\
Иванова сына Голицына человек Петр & Иванова сына Голицына человек Петр \\
Федоров учинил над нею насилное & Федоров в полытных сенях учинил над \\
блудное дело, от которого она и & нею насилное блудное дело, от которого \\
очреватела, и от тяжелой работы, & она и очреватела, и от тяжелой работы, \\
не донося урочных дней, выкинула & не донося урочных дней, выкинула \\
мертвого и, убоясь побой от господина & мертвого и, убоясь побой от господина \\
своего, бросила то мертвое тело в & своего, бросила то мертвое тело в \\
нужник, и никакой ему вред не чинила & нужник, и никакой ему вред не чинила и \\
и вовсем она Ирина утверждалась & вовсем она Ирина утверждалась против \\
против первого своего роспросу & первого своего роспросу и ничем не \\
и ничем не отменяла. & отменяла. \\
На пытке дано ей дватцать пять ударов. & На пытке дано ей дватцать пять ударов. \\
При оной пытке был присудствующий & При оной пытке был присудствующий \\
Иван Челищев.» & Иван Челищев»э7. \\
\hline
\end{tabular}

Несовершенства «приказного стиля» при записывании «пыточных речей» осознавались в качестве проблемы не только Н.С. Безобразовым: в 1738 г. в проекте «Об удержании пыток в малых делах» ту же обеспокоенность высказывал его автор, обер-секретарь Сената А.С. Сверчков. С его точки зрения, еще до окончания работы над «криминальным процессом» следовало отдельным указом «подтвердить», чтобы судьи записывали показания «точными» и «понятными» допрашиваемому словами, «не переворачивая» их «на приказной штиль» и, тем самым, внося «разность» в суть допроса. Сам «роспрос» должен был подписываться и обвиняемым, и допрашивавшим его судьей ${ }^{98}$.

Внимания заслуживает схожесть предложений обер-секретаря Сената А.С. Сверчкова и прокурора Сыскного приказа Н.С. Безобразова. У нас нет никаких свидетельств о личных контактах между Н.С. Безобразовым и А.С. Сверчковым, тем более что в 1742 г. последний ушел в отставку.

96. См., например: РГАДА, ф. 372, оп. 1, д. 1440, л. 25-26.

97. РГАДА, ф. 372, оп. 1, д. 2409, л. 9-9 об., 10. См. также: Оп. 1, д. 1440, л. 25-26, 27-27 об.; оп. 1, д. 2587 , л. 6,7.

98. РГАДА. ф. 342, оп. 1, д. 37, ч. 4, л. 12-12 об. 
Гипотетически можно предположить, что Безобразов был знаком с проектом Сверчкова: в 1748-1749 гг. он исполнял прокурорскую должность не только в Сыскном приказе, но и в Юстиц-, Мануфактур- и Вотчинной коллегиях, а также Судном приказе 99 . Может быть, идея «витала в воздухе», а Н.С. Безобразов предпринял конкретные шаги по ее реализации.

\section{Практика «розыскного» процесса и разработка проектов нового уложения}

Фигура Н.С. Безобразова представляет безусловной интерес и в связи с тем, что анализ его деятельности - сначала как прокурора (1741-1753), а затем как главного судьи Сыскного приказа (с 1753 г.) $)^{100}$ - позволяет поставить вопрос о степени влияния правоприменительной практики органов судопроизводства на выработку законодательных предложений по ее усовершенствованию. В 1754 г. сенатским указом от 24 августа Н.С. Безобразов был назначен «заседать» в уложенной комиссии ${ }^{101}$. Фактическая деятельность комиссии началась раньше, 3 августа 1754 г., а Безобразов и копиист Сыскного приказа Сергей Строкин явились в Санкт-Петербург не позднее 27 сентября того же года ${ }^{102}$. В июле 1755 г., когда вторая «криминальная» часть законопроекта была готова, Н.С. Безобразов и С. Строкин были отпущены в Москву ${ }^{103}$. Книги протоколов уложенной комиссии за 1754-1755 гг. не содержат информации об обсуждении проекта, фиксируя только факт чтения законов и апробации глав о преступлениях против церкви представителями духовенства ${ }^{104}$. Однако Н.С. Безобразов, прекрасно знавший особенности следственной деятельности Сыскного приказа, мог принимать в ней самое активное участие. Опосредованно об этом свидетельствует ряд статей 9 главы «О разных градусах пытки и каким градусом по какому делу патать» проекта «О розыскных делах и какия за разныя злодейства и преступления казни, наказания и штрафы положены», которые, по сути, предлагали узаконить существовавшую в Сыскном приказе практику пытки ${ }^{105}$.

Действующие указы определяли типы правонарушений, категории подозреваемых, к которым могла применяться пытка, но при этом сама «технология» пытки, ее «градусы» и этапы находились вне поля законодательного регулирования. Единственный указ, устанавливавший число ударов при

99. Северный, «Описание документов Сыскного приказа 1730-1763 гг. ...», с. 190.

100. РГАДА, ф. 248, д. 8122, ч. 3, л. 1028-1035.

101. ПСЗ, т. 14, № 10283 , с. 201.

102. РГАДА, ф. 342, оп. 1, д. 41, кн. 1, л. 3, 12-12 об.

103. РГАДА, ф. 342, оп. 1, д. 41, кн. 1, л. 44-45, 62, 63.

104. РГАДА, ф. 342, оп. 1, д. 41, кн. 1, л. 33-33 об., 43-43 об., 57-57 об.

105. См. ст.1, 3, 4, 5, 6, 7, 8, 9, 10, 11, 12: Проекты Уголовного Уложения, с. 46-48. 
первой (80), второй (120) и третьей (150) пытках, относился к 1673 г. ${ }^{106}$ и, как показывает изучение дел Сыскного приказа 1730-1750-х гг., на практике не использовался.

Законопроектные материалы уложенных комиссий 1700-х-1740-х гг. также не содержат конкретных предложений по урегулированию данного вопроса. Палата об уложении 1700-1703 гг. затрагивала пытку преимущественно с точки зрения уточнения видов уголовных дел и количества раз ее применения ${ }^{107}$. Уложенная комиссия 1720 -х гг. ограничилась только одной «сочиненной» статьей, не включив раздел «о градусах» пытки в проект «О процессе в криминальных или розыскных и пыточных делах» ${ }^{108}$. Последний факт заслуживает особого внимания, поскольку указанная статья была составлена с опорой на 8 главу «О самой пытке и градусах ее» «процесса Кромпейнова о криминальных делах» ${ }^{109}$.

Эрнст Фридрих Кромпейн, «дипломированный юрист, выпускник Иенского университета» и с 1720 г. асессор Юстиц-коллегии ${ }^{110}$, был привлечен к работе в уложенной комиссии 1720-1727 гг. в 1722 г. ${ }^{111}$ Фигура Кромпейна примечательна тем, что ему принадлежит авторство «Краткого изображения процессов» ${ }^{112}$. Будучи в комиссии, он принимал активное участие в разработке вышеназванного законопроекта «О процессе...», в основу

106. ПС3, т. 1, № 561. Тот факт, что данный указ был единственным, подтверждают выписки из предшествующего законодательства, использовавшиеся комиссией 1720 -х гг. при составлении проекта «О процессе в криминальных, розыскных или пыточных делах» (См.: РГАДА, ф. 342, оп. 1, кн. 33, ч. 2), а также подготовленные для уложенной комиссии 1754-1766 гг. Так, в последнем случае «по плану 2 части» к 9 главе «О пытке по разным градусам» были выписаны - 39, 100 и 103 статьи 21 главы Соборного Уложения, упоминавшийся выше указ 1657 г., рассматриваемый нами боярский приговор 1673 г., а также указы мая 1681 г. и июня 1742 г. о выборах палачей (РГАДА, ф. 342, оп. 1, д. 58, тетрадь 5). Сходная картина присутствует и примыкающих к «Обряду как обвиненный пытается» экстрактах из «законов, в чем и кого и как пытать велено» (РГАДА, ф. 7, оп. 2, д. 2116, л. 4-13).

107. См. дополнения к 22 главе Соборного уложения: РГАДА, ф. 342, оп. 1, д. 6, ч. VIII, л. 677-679 об., 682 об., 687 и т.д.

108. В структуре книги проекта «О процессе в криминальных или розыскных и пыточных делах», приведенной в исследовании А.С. Замуруева, название 8 главы дано в скобках как «О градусах в пытке, экзекуторах и палачах» (Замуруев, Paботы paзных лет, с. 205). В действительности сочиненная непосредственно комиссией глава с таким названием в проекте отсутствует. 7 и 8 главы носили идентичное название - «О действе пытки и о повиновении». Затем следовала глава 9 - «Как должен судья осторожно в пытках поступать» (РГАДА, ф. 342, оп. 1, кн. 33, ч. 2, л. 355), второе название - «Ежели судья меру пытки преступит и более пытать будет, нежели надлежит» (Там же, л. 357; Замуруев, Paботы paзныl лет, с. 205). Детальное сопоставление содержания 7 и 8 глав проекта требует отдельного исследования. Отметим только, что в 8 главе не идет речь о градусах пытки, палачах или экзекуторах (См.: РГАДА, ф. 342, оп. 1, кн. 33, ч. 2, л. 343-352 об.).

109. РГАДА, ф. 342, оп. 1, кн. 33, ч. 2, л. 39 об.-44.

110. Серов, Судебная реформа Петра I.., с. 263.

111. Замуруев, Работы разных лет, с. 190, 355.

112. П.О. Бобровский, Военные законы Петра Великого в рукописях и в первопечатных изданиях. СПб.,1887, с. 52-53, 69; Peterson, Peter the Great's Administrative and Judicial 
которого, со значительной переработкой и дополнениями, лег подготовленный Кромпейном «Процесс о криминальных или розыскных делах» (в бумагах комиссии он фигурирует под названием «процесс сочинения Кромпейнова о криминальных или розыскных делах» $\left.{ }^{113}\right)^{114}$.

В 1-4 статьях 8 главы «О самой пытке и градусах ее» Э. Кромпейн подробным образом изложил различные виды пыток, существовавшие в немецких, саксонских и «цесарских римских правах». По первым двум видам «прав» Кромпейном была описана «пятиобразная пытка», каждый «градус» которой зависел от характера подозрений и тяжести деяния, инкриминируемого подследственному, и ранжировался от простого раздевания, связывания и привода подследственного «к лестнице» до «испанского сапога» и прижигания «горючей серой» $(\text { Ст.1 })^{115}$. Статьи $4 \mathrm{a}^{116}-10$ вышеуказанной главы определяли очередность приведения к пытке фигурантов одного дела ${ }^{117}$. В примечаниях к артикулу, «сочиненному» комиссией на основании 8 главы «Кромпейнова процесса», особо отмечалось, что к нему «больше прилично сей ... главы ниже сего на 3-м листу на обороте 4[4a], 5, 6, 7, 8, 9, 10 пункты». В соответствии с этим комиссия полностью обошла молчанием вопрос о видах пыток, практически дословно воспроизведя 5 пункт 6 главы «Краткого изображения процессов», который предлагая судье «прежде» пытать тех, от кого «он мнит скорее уведать правду», затем, в случае неудачи, - того, кто наиболее «подозрителен явитца». Если все подозреваемые были «равны в подозрении», то начинать пытку следовало с «сына» или «жены», если они «между оными найдутся» ${ }^{118}$.

Изучение пыточных протоколов Сыскного приказа показывает, что проходящие по одному делу подозреваемые, в отношении которых было вынесено единое определение о пытке, действительно, могли «розыскиваться» вместе. Так, в феврале 1746 г. пытали уже упоминаемых С. Исаева, И. Стромынского, Н. Суету, В. Забалдина, С. Евдокимова ${ }^{119}$. В августе того же года совместно пытали воров-карманников Савелия Плохого, Андреяна Соколова, Ивана

Reforms.., p. 337; Чистяков, «Процессуальное законодательство», с. 799; Замуруев, Работы разных лет, с. 191; Серов, Судебная реформа Петра I, с. 133.

113. РГАДА, ф. 342, оп. 1, кн. 33, ч. 2, л. 1-69. «Процесс...» Э. Кромпейна, в первую очередь, основывался на шведском законодательстве (но не только) и воспринимался в комиссии как свод шведского права. В ряде подготовительных материалов к главам проекта «швецкий процесс», бывший наряду с Соборным уложением, «кормчей», «указами», «военными» постановлениями и датским законодательством одним из источников артикулов, «сочиненных» самой комиссией, назывался также «швецкий кромпейнов процесс» (Там же, л. 348, 350, 350 об., 357, 358 об., 359).

114. Замуруев, Работы разных лет, с. 204-205.

115. РГАДА, ф. 342, оп. 1, кн. 33, ч. 2, л. 39 об., 41-42 об.

116. В 8 главе «Процесса...» Э. Кромпейна присутствуют два артикула различного содержания под № 4. Для удобства второй артикул обозначен как 4а.

117. РГАДА, ф. 342, оп. 1, кн. 33, ч. 2, л. 43 об.-44.

118. РГАДА, ф. 342, оп. 1, кн. 33, ч. 2, л. 40; ПС3, т. 5, № 3006, с. 405.

119. РГАДА, ф. 372, оп. 1, д. 1440, л. 55-57. 
Серкова, Михаила Коровина ${ }^{120}$. Есть основания предполагать, что мужчин и женщин, участников одного дела, пытали в застенке совместно, то же касалось и несовершеннолетних преступников ${ }^{121}$. Пытке предшествовал осмотр колодников, результаты которого могли, видимо, влиять на количество ударов, даваемых в процессе пытки, или вообще освобождать от нее ${ }^{122}$. В 1742 г. «взявший грабежом» личные вещи «незнаемо какого пьяного» 24-летний 123 «ловчего Саввы Ярославцова человек» Семен Тарташев, «по мирскому званию Кадия», был приговорен к простому поднятию на дыбу и допросу «при розыске других колодников». Можно предположить, что он находился в плохом физическом состоянии, поскольку другого соучастника преступления, 23-летнего фабричного Осипа Соколова, давшего сходные признательные показания, судьи предписали пытать ${ }^{124}$. Пытка откладывалась, если колодник был болен. 15 января 1758 г. обвинявшийся в разбоях и приговоренный к пытке Трофим Иванов сын Соколов был взят «для пытки в застенок, токмо не пытан за болезнию». 17 февраля Сыскной приказ «определил» Соколова пытать «по прежней резолюции»: постановление, однако, не вступило в силу, поскольку в застенке «по усмотрению присутствующих» он «явился малоростен». В результате было принято решение Соколова не пытать, а «спросить у дыбы» и направить запрос в Камер-коллегию о его возрасте. Она подтвердила малолетство Соколова, после чего пытка к нему не применялась ${ }^{125}$. Малолетних подозреваемых «розыскивали» плетьми, а не кнутом, однако, следственные действия в их отношении все равно носили название пытки ${ }^{126}$. Данные по концу 1750-х-началу 1760-х гг. свидетельствуют, что в ряде случаев применительно к несовершеннолетним преступникам источником процессуальных действий был 10 пункт 6 главы «Краткого изображения процессов» ${ }^{127}$, освобождавший от пытки «недорослей», лиц старше семидесяти лет и беременных женщин (кроме особо тяжких преступлений $)^{128}$.

120. РГАДА, ф. 372, оп. 1, д. 1534, л. 21-22 об., 23-27.

121. Единый протокол о пытке мужчин, женщин и малолетних, проходящих по одному делу, был вынесен 27 января 1742 г. (РГАДА, ф. 372, оп. 2, д. 113, л. 129-134). См. также: РГАДА, ф. 248, оп. 126, д. 4918, л. 98-98 об.

122. Северный, Описание документов Сыскного приказа 1730-1763 г2., с. 96-97.

123. РГАДА, ф. 372, оп. 1, ч. 2, д. 6210 , л. 50 об.

124. РГАДА, ф. 372, оп. 2, д. 113, л. 129-134.

125. РГАДА, ф. 248, оп. 126, д. 4819, л. 124,126-126 об.

126. «Варварской школы учеников Леонтья Юдина, Ивана Тареева, Ивана Ракова, Степана Копылова за малолетством бить при розыске, пытать плетьми, и спрашивать и в других воровствах с подлинною очисткою, и на кого означенные все колодники будут показывать какое воровство, тех оговорных сыскивая, роспрашивать...» (РГАДА, ф. 372, оп. 2, д. 113, л. 134). См. также: РГАДА, ф. 248, оп. 126, д. 4918, л. 1041, 1056-1059 об.

127. РГАДА, ф. 248, оп. 126, д. 4918.

128. ПС3, т. 5, № 3006, с. 407. Г.О. Бабкова, «Безгласные граждане»: малолетние преступники в судебной системе России 1750-1760-х гг.: препринт WP19/2012/04, М., 2012, c. $11-22$. 
Наряду с пыточными протоколами восстановить процедуру пытки позволяет 9 глава «О разных градусах пытки...» проекта «О розыскных делах...», в работе над которым, в 1754-1755 гг. принимал участие прокурор Сыскного приказа Н.С. Безобразов. Перед пыткой колодник забирался в застенок, где его раздевали и подымали на дыбу. Как уже отмечалось, в рассмотренных нами определениях Сыскного приказа отсутствовали указания на то, сколько раз пытать (за исключением случаев изменения показаний). Видимо, в каждом конкретном случае конечное решение зависело от «важности преступления и находящихся по делу подозрений» ${ }^{129}$. Последние обстоятельства влияли и на выбор «градуса» пытки. Проект описывает три «градуса»: 1) «подъем на дыбу», 2) «подъем со стряской без огня», 3) «с стряскою огонь, когда приводного на виске еще сверх того веником или утюгом жгут» ${ }^{130}$.

В изученном нами комплексе дел обвиняемые были подвергнуты 1 и 3 градусам пытки, но без «стряски». Пытка включала подъем «на виску», т.е. дыбу, который сопровождался нанесением ударов. Алгоритм «зжения огнем», которому подвергались обвиняемые как мужского, так и женского пола, был тот же ${ }^{131}$. Между пытками проходило от 2 недель до месяца, т.е. время, достаточное для восстановления здоровья подследственного.

Имеющиеся данные не позволяют сделать вывод о каких-либо существенных отличиях в расследовании дел в зависимости от пола преступника: и для мужчин, и для женщин следственные мероприятия были одинаковы. Вместе с этим, во время пытки женщины могли получать меньше ударов кнута. Интересно, что проект «О розыскных делах...» как раз предлагал действовать по отношению к женщинам «с умеренностью».

Количество ударов и время нахождения на дыбе находилось в зависимости от усмотрения судьи и детерминировалось физическим состояние преступника $^{132}$. По сути, не ссылаясь на данный источник напрямую, практика руководствовалась 4 пунктом 6 главы воинских процессов, отдававшим «на рассуждение судейское» принятие решения о степени пытки и предписывавшем сначала оценить «количество дела» и «особ, которые к пытке приводятся, рассмотреть» ${ }^{133}$. Фактически судьи реализовывали и другое положение той же статьи «Краткого изображения процессов» - «быть осторожну» при пытке с тем, чтобы «... которого пытает истязанием не озлобить» ${ }^{134}$, назначая

129. Проект Уголовного Уложения, с. 46.

130. Проект Уголовного Уложения, с. 46.

131. РГАДА, ф. 372, оп. 1, д. 1534, л. 24-25 об., 27 об. и далее; оп. 1, д. 1271, л. 3-9.

132. «Сколько же ударов при каждом градусе пытки порознь давать и колокое время приводному на дыб висеть, и колоко стряскам быть, того точно определить невозможно, понеже судьям надлежит в том поступать по состоянию и крепости подозрительного...» (Проект Уголовного Уложения, с. 47).

133. ПСЗ, т. 5, № 3006, с. 404.

134. ПСЗ, т. 5, № 3006, с. 404. 
значительно меньше ударов кнута, чем предписывало законодательство (об этом см. выше).

Максимальное количество ударов, которое фигурирует в рассмотренных нами делах, -35 (в случае разбоя) ${ }^{135}$. В делах о детоубийстве оно могло варьироваться от 15 до 25 (в среднем давалось около 20 ударов) ${ }^{136}$. Во время второй и третьей пытки количество ударов могло как увеличиваться $(15,21,20)^{137}$, так и уменьшаться $(20,20,16)^{138}$. Данные о числе ударов, дававшихся в застенке при расследовании политических преступлений в первой половине XVIII в. (в среднем от 15 до $30^{139}$ ), свидетельствует, что практика Сыскного приказа не была исключением: судебные органы приговаривали подозреваемого к пытке, однако поступали осмотрительно, не желая, видимо, превращать пытку в наказание. Отметим, что в ряде дел «указные розыски», под которыми колодник «утверждался» на том, что было сказано в допросе, засчитывались в виде наказания ${ }^{140}$. Это дает основание предположить, что в Сыскном приказе действовало правило «трех пыток», в общих чертах изложенное в 7 пункте «Краткого изображения процессов»: «ежели трижды пытку снесет ..., то оного уже более допрашивать не надлежит, но, взяв от него полное число порук, ... освободить» ${ }^{141}$. В итоге, выяснение истины зависело от возможной осведомленности обвиняемого о существующей практике расследования преступлений и от его физической выносливости.

\section{Влияние практики «розыскного» процесса на упразднение пытки}

Изученный комплекс дел позволяет поставить под вопрос эффективность пытки как следственного метода в общеуголовных процессах. Ни в одном из рассмотренных дел Сыскного приказа 1730-1750-х гг. пытка не привела к открытию новых обстоятельств. Подозреваемые, во-первых, не меняли своих показаний (из дела в дело повторяется шаблонная формулировка «с пытки

135. РГАДА, ф. 372, оп. 1, д. 1440, л. 25-26, 55-57.

136. См., например: РГАДА, ф. 372, оп. 1, д. 481, л. 11 об.; д. 1271, л. 11; л. 2409, л. 12 и т.д.

137. РГАДА, ф. 372, оп. 1, д. 481, л. 7, 10, 10 a.

138. РГАДА, ф. 372, оп. 1, д. 6064, л. 6 об., 7, 7 об.

139. Анисимов, Дыба и кнут..., с. 432-432; В.И. Веретенников, История Тайной канцелярии петровского времени, Харьков, 1910, с. 198.

140. См.: РГАДА, ф. 372, оп. 1, д. 537; д. 6064. Отметим, что в качестве наказания могла засчитываться и одна пытка (Там же, д. 721, 809). На подобную практику при наказании политическим преступников в конце XVII в. указывает Тельберг (Тельберг, Очерки политического суда и политических преступлений, с. 206).

141. ПСЗ, т. 5, № 3006, с. 406. 
показал/а то же, что в роспросе говорил/а»), а во-вторых, не «винились» в совершении других деяний ${ }^{142}$.

Тем не менее, суды в России первой половины XVIII в. продолжали приговаривать заключенных к пытке, не смотря на ее явную неэффективность как следственного действия. Параллельно в уголовно-процессуальных проектах четко формулировались мысль о невозможности объективно расследовать дело на основании «вымученных» показаний. Пытка начинала мыслиться «как опасное и непостоянное дело», которое «часто и самую правду обманывает» ${ }^{143}$. Как писал А.С. Сверчков, ее применение, особенно в незначительных делах, не было «прилично по ситуации или состоянию Российского государства уложенья и указов», поскольку обличать следовало «не спиною ... другаго или перепытоватца, кто вытерпел, тому и верить», а «доказательством и обличением». Только так можно было эффективно бороться с преступностью, лишая преступников «надежды..., дабы они могли оттерпетца пыткою и тем быть правы» ${ }^{144}$. Видимо, не случайно начиная с 1750 -х гг. в законодательстве наметилась тенденция изъятия от пытки отдельных социальных групп, видов деяний и территорий. Указом от 9 января 1752 г. пытка была запрещена во вновь присоединенных шведских губерниях, «ибо де пытка во всей земле по тамошним правам запрещена» ${ }^{145}$. В 1751 и 1753 гг. последовали постановления о замене пытки на пристрастные допросы с использованием кошек и плетей в корчемных делах ${ }^{146}$. В соответствии с «Инструкцией главным сыщикам» от 19 ноября 1756 г., в делах дворян и офицеров, пойманных по подозрению в разбое и грабеже, пытка должна была применяться только с санкции Сената ${ }^{147}$. Указанный процесс был следствием целого ряда причин. В равной степени в нем нашло свое отражение и осознание неэффективности пытки как следственного действия, и социально-политические стремления дворянства, проявлявшиеся, прежде всего, во «всеобщих претензиях к существующим формам правового регулирования» ${ }^{148}$, и общая тенденция «значительного смягчения нравов», бывшая следствием моратория на смертную казнь в России при Елизавете Петровне ${ }^{149}$.

142. РГАДА, ф. 372, оп. 1, д. 721, л. 12; д. 957, л. 14-15, 21, 22, 24; д. 2409, л. 9, 10; д. 6064, л. 6 об.-7 об.; оп. 1, д. 1440, 1534.

143. РГАДА, ф. 342, оп. 1, кн. 33, ч. 2, л. 344.

144. РГАДА, ф. 342, оп. 1, д. 37, ч. 4, л. 5.

145. ПСЗ, т. 13, № 9923.

146. ПСЗ, т. 13, № 9920 (п. 8); 10072 (п. 8); 10073 (п. 7).

147. «по следствию и розыску дойдут до пытки ..., в чем они виновны о винах их, не производя пыток, присылать ... выписки ... в Сенат ... и ожидать на то указу, а до того времени держать их под крепким караулом» (ПС3, т. 13, № 10650, п. 3).

148. О.А. Омельченко, «Законная монархия» Екатерины ІІ: Просвещзенный абсолютизм в России, М., 1993, с. 25.

149. Анисимов, Дьба и кнут, с. 441. 
Л. Сильверман, исследуя пытку во Франции в раннее новое время, связывает ее постепенное изживание с общим изменением отношения к боли, телу и «понятию правды», постепенно происходившим в XVII-XVIII вв. С ее точки зрения, еще задолго до того, как началось публичное обсуждение и осуждение пытки в легальном контексте, традиционно связываемое с делом Калласса 1762 г., ее «культурный смысл» подвергся кардинальной трансформации. Пытка перестала мыслиться средством элиминирующим человеческую волю с целью открытия «спонтанной» правды, которая при изначальной поврежденности человека не могла быть сознательным, волевым актом. Судебные инстанции только «отражали» происходящие изменения, применяя пытку до тех пор, пока она имела культурное значение ${ }^{150}$.

Как представляется, в России в первой половине XVIII в. могли иметь место схожие процессы. Об изменении отношения к правде свидетельствует приведенная выше мысль А.С. Сверчкова о том, что истина не могла зависеть от способности «спиною обтерпетца» ${ }^{151}$. О трансформации восприятия пытанного тела свидетельствует постепенное упразднение в 1730-1760-х гг. в Москве древней практики выводить колодников для прошения милостыни. Начиная с 1722 г. правительство последовательно предпринимало попытки побороть массовое бродяжничество колодников. Всего с 1722 по 1761 гг. было издано 10 указов ${ }^{152}$, одним из лейтмотивов которых (наряду с чисто практическим желанием очистить улицы от попрошаек или направить их на казенные работы) было стремление убрать из города претерпевшее пытки тело. Сенатский указ от 23 декабря 1736 г. мотивировал запрет на сбор милостыни «безодежными» колодниками тем, что они отпускались «на связке ... без одежды в одних ветхих рубахах, а другие пытаны, прикрывая одни спины кровавыми рубашками» и демонстрируя «раны битыя». Отныне позволялось выводить на улицы только одетых арестантов, «а кормить... безодежных» за счет тех денег, которые будут собраны «прочими одежными колодниками» ${ }^{153}$. Указ Сената от 29 января 1749 г. ввел запрет на все категории заключенных вне зависимости от наличия на них одежды, еще раз акцентируя недопустимость выставления напоказ пытанного тела ${ }^{154}$. Данное предписание неоднократно подтверждаюсь в 1752, 1753, 1754, 1756 и 1761 гг. Колодники «на связке ...

150. L. Silverman, Tortured Subjects: Pain, Truth and the Body in Early Modern France, Chicago, 2001, p. 3-20.

151. РГАДА. ф. 342 , оп. 1 , д. 37 , ч. 4 , л. 3 об.

152. ПСЗ, т. 6, № 4094, 4111; т. 9, № 7132; т. 10, № 7566; т. 12, № 9068; т. 13, № 9571, 10121; т. 14, № 10202, 10660 Т. 15, № 10824, 11282; РГАДА, ф. 372, оп. 1, д. 3359, л. 16-16 об.

153. ПСЗ, т. 9, № 7132, с. 1011-1012.

154. «многие колодники пытанные в разодранных платьях, что едва тела лоскутьями прикрыты, стоя скованные на Красной площади и по другим знатным улицам, необычно с криком поючи, милостыни просят, тако ж ходят по рядам и по всей Москве по улицам» (ПС3, т. 13, № 9571, с. 2-3). 
после пыток и ... без рубах обнажены, причем точию спины кровавыми рубахами прикрыты» ${ }^{155}$ более не могли оставаться частью городского, а в более широком смысле - культурного пространства.

\section{Заключение}

В качестве предварительных итогов исследования, которое, безусловно, должно быть продолжено с привлечением более широкого круга источников как практического, так и теоретического характера, отметим, что пытка в России в первой половине XVIII в. применялась в строгом соответствии с законом. Государство не считало правомерным бесконтрольно использовать боль в судебно-следственных целях, контролируя легитимность принятия решений о наложении пытки через институт прокуроров. В ситуации явного недостатка и нечеткости законодательства, судопроизводственная практика вырабатывала собственную процессуальную «традицию», которая, в целом, коррелировалась с действующим законодательством. Новые постановления верховной власти достаточно быстро принимались к исполнению, а в отдельных случаях - инициировались снизу. Материалы уложенных комиссий первой половины XVIII в. достаточно ясно артикулировали идею о необходимости урегулирования и ограничения сферы и пределов применения пытки, начиная подвергать сомнению саму возможность получения достоверных показаний при помощи насилия. Повседневная практика «розыскного» процесса по общеуголовным делам, обнаруживавшая крайне низкую процессуальную эффективность пытки, учитывалась при разработке проектов нового законодательства и сыграла свою роль при постепенном упразднении пытки как неотъемлемой части уголовного процесса в России во второй половине XVIII в.

National Research University Higher School of Economics

Department of Political History

eakelev@hse.ru

gbabkova@hse.ru 